\title{
Molecular characterization of pyrimidine biosynthesis genes from the thermophile Bacillus caldolyticus
}

\author{
Sa-Youl Ghim, † Preben Nielsen and Jan Neuhard
}

Department of Biological

Chemistry, Institute of Molecular Biology,

University of Copenhagen, Solvgade 83, DK-1307,

Copenhagen K, Denmark

\author{
Author for correspondence: Jan Neuhard. Tel: +45 35 322002. Fax: + 4535322040 . e-mail: \\ neuhard@mermaid.molbio.ku.dk
}

The genes encoding the six pyrimidine biosynthesis enzymes from the thermophile Bacillus caldolyticus were characterized by cloning and complementation in Escherichia coli, and by nucleotide sequence analysis. Nine cistrons are clustered within an $11 \mathrm{~kb}$ region of the chromosome, the gene order being: orf1-pyrB-pyrC-pyrAa-pyrAb-orf2-pyrD-pyrF-pyrE. This organization of the cluster is very similar to that of the pyr operon of Bacillus subtilis. Different parts of the $B$. caldolyticus cluster were cloned in two orientations in the expression shuttle vector pHPS9. Complementation studies in B. subtilis established that expression of the pyr genes was dependent on the vector-borne promoter, suggesting that they are part of an operon, and that the native promoter of the operon had not been cloned. The deduced amino acid sequence of the individual cistrons showed 49 to $78 \%$ identity with the corresponding $B$. subtilis cistrons. Measurements of the aspartate transcarbamylase (pyrB), orotidine monophosphate decarboxylase (pyrf) and orotate phosphoribosyltransferase (pyrE) levels in cells grown under different conditions indicated that expression of the operon is repressed 7-9-fold by addition of uracil to the growth medium. Based on the nucleotide sequence in the intercistronic region between orf1 and pyrB a regulatory mechanism involving transcriptional termination and antitermination is proposed to control expression of the operon.

Keywords: Bacillus caldolyticus, pyrimidine biosynthesis genes, thermophile

\section{INTRODUCTION}

The extreme thermophile Bacillus caldolyticus together with Bacillus caldotenax and Bacillus caldovelox were isolated as single isolates from a hot spring in Yellowstone National Park, USA (Heinen \& Heinen, 1972). The optimal growth temperature for $B$. caldolyticus is about $72^{\circ} \mathrm{C}$ and the maximal temperature for growth about $82{ }^{\circ} \mathrm{C}$ (Claus \& Berkley, 1986). Differences in the $\mathrm{mol} \% \mathrm{G}+\mathrm{C}$ in the genomes and in DNA/DNA homologies showed that $B$. caldolyticus does not belong to the same species as B. caldotenax and B. caldovelox (Sharp et al., 1980). Recent taxonomic studies further showed that $B$. caldolyticus does not belong to the Bacillus stearothermophilus group either (De Bartolomeo et al., 1991).

† Present address: Department of Biochemistry, University of Illinois at Urbana-Champaign, 323 Roger Adams Laboratory, IL 61801, USA.

The EMBL accession number for the sequence reported in this paper is X73308 (BCPYR).
Thermophilic micro-organisms have received increasing interest in recent years due to their potential use as sources for thermostable enzymes of industrial interest. A number of genes from thermophilic Bacillus strains have been characterized and the deduced amino acid sequences of the gene products compared with their mesophilic counterparts. In many instances the aim was to gain information on the structure-thermostability relationships of the encoded proteins (Eijsink et al., 1992; Schlatter et al., 1987; Van den Burg et al., 1991; Zuber, 1988; Zülli et al., 1987). However, very little is known about the genetic organization and control of expression of biosynthetic pathways in thermophilic Bacillus strains.

Pyrimidine biosynthesis follows the same pathway in all organisms. Six enzyme reactions catalyse the conversion of glutamine (ammonia), bicarbonate, aspartate and phosphoribosylpyrophosphate to UMP, the common precursor of all other pyrimidine nucleotides. In Escherichia coli and Salmonella typhimurium the enzymes are 
Table 1. Bacterial strains and plasmids

\begin{tabular}{|c|c|c|}
\hline $\begin{array}{l}\text { Strains and } \\
\text { plasmids }\end{array}$ & Relevant characteristics & $\begin{array}{l}\text { Reference } \\
\text { or source* }\end{array}$ \\
\hline \multicolumn{3}{|l|}{ Strains } \\
\hline \multicolumn{3}{|l|}{ B. caldolyticus } \\
\hline DSM 405 & Wild-type & DSM \\
\hline \multicolumn{3}{|l|}{ B. subtilis } \\
\hline 6GM15 & 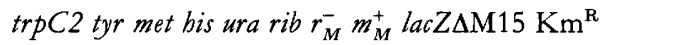 & Haima et al. (1990b) \\
\hline ED215 & met pyrE305 & BGSC $1 \mathrm{~A} 322$ \\
\hline ED216 & $\operatorname{trp} C 2 \operatorname{pyr} C$ & BGSC 1 A 394 \\
\hline ED217 & $\operatorname{trpC} 2$ pyrF & BGSC $1 \mathrm{~A} 400$ \\
\hline ED316 & $\operatorname{trp} C 2$ pyrB & BGSC 1 A 392 \\
\hline ED318 & $\operatorname{trp} C 2$ pyrD & BGSC 1 A396 \\
\hline ED364 & $\operatorname{pyr} A$ & BGSC 1A391 \\
\hline \multicolumn{3}{|l|}{ E. coli } \\
\hline SØ268 & $\begin{array}{l}\text { pyrE60 cdd thi-1 argE3 bis-4 pro A2 thr-1 leu-6 mtl-1 } \\
\text { xyl-5 ara-14 gal-K2 lacY1 str-31 supE44 }\end{array}$ & JF611, J. Friesen \\
\hline Sø990 & $\begin{array}{l}\text { pyrB59 argH1 thi-1 bisG1 purF1 mtl-2 } x y l-7 \text { malA1 } \\
\text { ara-13 lacY1 or lacZ4 str A ton tsx supE44? }\end{array}$ & CGSC 4517 \\
\hline SØ1209 & carB $\Delta 8$ thr thi lac $r_{K}^{-} m_{K}^{+}$ & $\begin{array}{l}\text { JL2944, } \\
\text { J. L. Ingraham }\end{array}$ \\
\hline SØ1263 & $\Delta$ pyrC araD139 $\Delta($ argF-cod-lac $) U 169$ rpsL thi & K. F. Jensen \\
\hline SØ3539 & araD139 $\Delta($ ara-leu $) 7697 \Delta l a c 74$ gal4 bsdR rpsL & $\begin{array}{l}\text { MC1061, } \\
\text { N. P. Minton }\end{array}$ \\
\hline SØ4058 & $\begin{array}{l}\text { pyrD:: } \mathrm{Km}^{\mathrm{R}} \text { araD139 } \Delta(\text { ara-leti }) 7697 \Delta \text { lac } 74 \text { gal4 } \\
\text { bsdR rpsL }\end{array}$ & L. Linde \\
\hline SØ5009 & $\begin{array}{l}\text { pyrF30 araD139 } \Delta(\text { ara-leu }) 7697 \Delta l a c 74 \text { gal4 bsdR } \\
\text { rpsL }\end{array}$ & L. Stauning \\
\hline \multicolumn{3}{|l|}{ Plasmids } \\
\hline pHPS9 & $\mathrm{Cm}^{\mathrm{R}} \mathrm{Er}^{\mathrm{R}}$ cat-86:: lac $Z a$ PT1060-pUC9 derivative & Haima et al. (1990a) \\
\hline pHPSY4 & $\begin{array}{l}4.65 \mathrm{~kb} X b a \mathrm{I} \text { fragment from } \mathrm{pSY} 31 \text { with } p y r A a \\
\text { and } A b \text { in } S m a \mathrm{I} \text { site }\end{array}$ & This study \\
\hline pHPSY5 & Same insert as pHPSY 4 with reversed orientation & This study \\
\hline pHPSY6 & $\begin{array}{l}3 \cdot 1 \mathrm{~kb} S m a \mathrm{I} \text { fragment from } \mathrm{pSY} 17 \text { with } p y r B \text { and } \\
C \text { in } S m a \mathrm{I} \text { site }\end{array}$ & This study \\
\hline pHPSY7 & Same insert as pHPSY6 with reversed orientation & This study \\
\hline pHPSY8 & $\begin{array}{l}2.1 \mathrm{~kb} B a m \mathrm{HI} \text { fragment from pHPSY } 10 \text { with orf } 2 \\
\text { and } p y r D \text { in Bam HI site }\end{array}$ & This study \\
\hline pHPSY9 & Same insert as pHPSY8 with reversed orientation & This study \\
\hline pHPSY10 & $\begin{array}{l}2 \cdot 1 \mathrm{~kb} \text { EcoRI-PvuII fragment from } \mathrm{pSY} 2 \text { with orf } 2 \\
\text { and } p y r D \text { in EcoRI-SmaI sites }\end{array}$ & This study \\
\hline pJS21 & $\begin{array}{l}2.75 \mathrm{~kb} S p h \mathrm{I} \text { fragment from p. IS5 with } p y r F \text { and } E \\
\text { in } S p h \mathrm{I} \text { site of pHPS9 }\end{array}$ & This study \\
\hline $\begin{array}{l}\text { pJS22 } \\
\text { pUC18, } 19\end{array}$ & $\begin{array}{l}\text { Same insert as } \mathrm{pJS} 21 \text { with reversed orientation } \\
\mathrm{Ap}^{\mathrm{R}}\end{array}$ & This study \\
\hline pJS5 & $\begin{array}{l}2 \cdot 8 \mathrm{~kb} N r u \mathrm{I}-E c o \mathrm{RV} \text { fragment from } \mathrm{pSY} 4 \text { with } \\
\text { pyrF and } E \text { in pUC18 HincIl site }\end{array}$ & This study \\
\hline PJS7 & $\begin{array}{l}1.6 \mathrm{~kb} \text { fragment from } \mathrm{pJS} 5 \text { with } p y r F \text {, by } P_{s t \mathrm{I}} \\
\text { deletion }\end{array}$ & This study \\
\hline pPM4 & $\begin{array}{l}1.2 \mathrm{~kb} N s i \mathrm{I}-H \text { indIII fragment from } \mathrm{pJS} 7 \text { with } \\
\text { pyrF, in pUC18 PstI-HindIII sites }\end{array}$ & This study \\
\hline pPM15 & $\begin{array}{l}1.7 \mathrm{~kb} \text { fragment with pyrE by HincII-SmaI deletion } \\
\text { of } \mathrm{pJS} 5\end{array}$ & This study \\
\hline pSY1 & $\begin{array}{l}4.7 \mathrm{~kb} C l a \mathrm{I} \text { fragment with orf } 2, \operatorname{pyr} D, F \text { and } E \text { in } \\
\text { pUC19 AccI site. From ClaI library }\end{array}$ & This study \\
\hline pSY2 & Same insert as pSY1 with reversed orientation & This study \\
\hline
\end{tabular}


Table 1. (continued).

\begin{tabular}{|c|c|c|}
\hline $\begin{array}{l}\text { Strains and } \\
\text { plasmids }\end{array}$ & Relevant characteristics & $\begin{array}{l}\text { Reference } \\
\text { or source* }\end{array}$ \\
\hline pSY4 & $\begin{array}{l}6.5 \mathrm{~kb} \mathrm{BamHI} \text { fragment with orf } 2, \operatorname{pyr} D, F \text {, and } E \\
\text { in pUC19 Bam HI site. From Bam HI library }\end{array}$ & This study \\
\hline pSY5 & $\begin{array}{l}4.3 \mathrm{~kb} S p h \mathrm{I} \text { fragment with } p y r F \text { and } E \text { in pUC19 } \\
S p h \text { I site. From } S p b \mathrm{I} \text { library }\end{array}$ & This study \\
\hline pSY6 & $\begin{array}{l}11 \cdot 3 \mathrm{~kb} \text { HindIII fragment with } p y r C, A a, A b, \operatorname{orf} 2 \text {, } \\
D, F \text { and } E \text { in pUC19 HindIII site. From HindIII } \\
\text { library }\end{array}$ & This study \\
\hline pSY10 & $\begin{array}{l}7 \mathrm{~kb} H \text { indIII-ClaI fragment from pSY6 with } p y r C \\
\text { and } A a \text { in pUC18 HindIII- } A c c \text { I sites }\end{array}$ & This study \\
\hline pSY15 & $\begin{array}{l}7 \cdot 1 \mathrm{~kb} \text { fragment with } p y r B, C, A a \text { and } A b \text { in } \\
\text { pUC19 BamHI site. From partial Sau3AI library }\end{array}$ & This study \\
\hline pSY16 & $\begin{array}{l}4.7 \mathrm{~kb} \text { insert with pyr } A b \text { in pUC19 Bam HI site. } \\
\text { From partial Sau3AI library }\end{array}$ & This study \\
\hline pSY17 & $\begin{array}{l}3.1 \mathrm{~kb} \text { SmaI fragment from pSY15 with pyrB and } \\
C \text { in pUC19 SmaI site }\end{array}$ & This study \\
\hline pSY18 & Same insert as pSY17 with reversed orientation & This study \\
\hline pSY31 & $\begin{array}{l}4.7 \mathrm{~kb} N a r \mathrm{I}-H i n \mathrm{dIII} \text { fragment from } \mathrm{pSY} 15 \text { with } \\
\text { pyr } A a \text { and } A b \text { in pUC18 } A c c \mathrm{I}-H i n \mathrm{dIII} \text { sites }\end{array}$ & This study \\
\hline
\end{tabular}

* DSM, Deutsche Sammlung für Mikroorganismen und Zell Kulturen, Braunschweig, Germany; BGSC, Bacillus Genetic Stock Center, Ohio State University, Columbus, OH, USA; CGSC, E. coli Genetic Stock Center, Yale University, New Haven, CT, USA. K. F. Jensen, L. Linde and L. Stauning. Dept Biol. Chem., Univ. Copenhagen, Denmark; J. Friesen, Hospital for Sick Children, Toronto, Canada; N. P. Minton, Microbial Technol. Lab., Salisbury, UK; J. L. Ingraham, Dept Bacteriol., Univ. Calif., Davis, CA, USA.

encoded by six genetically unlinked loci (Neuhard \& Nygaard, 1987). Expression of these genes and small operons are non-coordinately regulated by an interplay of the intracellular nucleotide pools. The pyrB and pyrE genes are regulated through UTP-sensitive transcriptional attenuation (Poulsen et al., 1984; Roland et al., 1985), whereas $\operatorname{pyr} C$ and $\operatorname{pyr} D$ expression is controlled through CTP/GTP-sensitive selection of the transcriptional start site which in turn influences translation initiation due to formation of secondary structures on the RNA (Sørensen \& Neuhard, 1991; Sørensen et al., 1993; Wilson et al., 1992). The pyr genes in B. subtilis are organized in a single operon with the gene order pyrB-C-A-D-F-E (Lerner et al., 1987; Quinn et al., 1991). Expression of the operon is coordinately repressed by a uracil compound by an unknown mechanism (Asahi et al., 1989; Paulus et al., 1982).

In this paper we report the cloning and characterization of the pyrimidine biosynthesis genes from B. caldolyticus. Our data indicate that the genes belong to a single operon with the same overall organization as found for the pyr operon of B. subtilis, and that expression of the operon is repressed in cells grown in the presence of uracil.

\section{METHODS}

Bacterial strains, plasmids and growth conditions. The bacterial strains and plasmids used are described in Table 1. B. caldolyticus DSM405 was grown at $60^{\circ} \mathrm{C}$ in mineral salts medium
162 (Degryse et al., 1978) supplemented with either yeast extract $\left(2.5 \mathrm{~g}^{-1}\right)$ and tryptone $\left(2.5 \mathrm{~g} \mathrm{l}^{-1}\right)$, or with ammonium chloride $(10 \mathrm{mM}), 0.5 \%$ glucose and $0.2 \%$ vitamin-free Casamino acids. E. coli was grown at $37^{\circ} \mathrm{C}$ in LB medium (Sambrook et al., 1989) or in $\mathrm{AB}$ medium with $0.2 \%$ glucose and $0.2 \%$ vitamin-free Casamino acids (Clark \& Maaløe, 1967). B. subtilis was grown at $37^{\circ} \mathrm{C}$ in LB medium or in Spizizen mineral salts medium (Spizizen, 1958) with $0.5 \%$ glucose as carbon source. As solid medium for $B$. subtilis Spizizen mineral salts medium supplemented with $0.2 \%$ glycerol and $0.2 \%$ glutamate was employed. The following nutrients were added when required: uracil $\left(20 \mu \mathrm{g} \mathrm{ml}^{-1}\right)$, hypoxanthine $\left(15 \mu \mathrm{g} \mathrm{ml}^{-1}\right)$, individual amino acids $\left(50 \mu \mathrm{g} \mathrm{ml}^{-1}\right)$. Antibiotics were used at the following concentrations: ampicillin $\left(100 \mu \mathrm{g} \mathrm{ml}^{-1}\right)$, chloramphenicol $\left(5 \mu \mathrm{g} \mathrm{ml}^{-1}\right)$, tetracycline $\left(10 \mu \mathrm{g} \mathrm{ml}^{-1}\right)$. X-Gal (5-bromo-4-chloro-3-indolyl $\beta$-D-galactopyranoside) was used at a final concentration of $40 \mu \mathrm{g} \mathrm{ml}{ }^{-1}$.

Molecular cloning and DNA manipulations. Chromosomal, plasmid and M13 DNA was prepared as described by Sambrook et al. (1989). Restriction endonucleases, mung bean nuclease, the Klenow fragment of DNA polymerase I and T4 DNA ligase were purchased from Boehringer or Promega and used in accordance with the specifications given by the manufacturers. $E$. coli cells were made competent for transformation by the $\mathrm{CaCl}_{2}$ method (Sambrook et al., 1989). Competence in B. subtilis was induced by the method of Boylan et al. (1972). DNA sequencing was accomplished by the chain-termination method (Sanger et al., 1977) using M13mp18/19 or pUC18/19 as vectors. ssDNA was sequenced with the Sequenase kit (US Biochemical Corp.) with 7-deaza-dGTP to alleviate the problem of compression of the $\mathrm{G}+\mathrm{C}$-rich regions frequently encountered in B. caldolyticus DNA. For sequencing dsDNA the template 
was prepared by the CTAB-DNA precipitation method (Del Sal et al., 1989), and a TaqTrack sequencing system (Promega). Computer-assisted sequence analysis was done with University of Wisconsin GCG software packages (Devereux et al., 1984) on a VAX computer. The deduced amino acid sequences were compared with the Swiss Prot databank and the NBRF protein database by using the FASTA program (Pearson \& Lipman, 1988). RNA secondary structure analysis was performed with the FOLD program using the algorithm of Zuker \& Stiegler (1981).

Polymerase chain reaction (PCR). The intercistronic region between $p y r F$ and $p y r E$ was amplified using total chromosomal B. caldolyticus DNA and two synthetic primers: the pyrF primer, 5' GCAACACGAATGGAACGGAGG 3', corresponding to nucleotides 9221 to 9241 (Fig. 2); and the pyrE primer $5^{\prime}$ ATTTCAAGCCCGAGGACCAGG 3', complementary to nucleotides 9724 to 9744 (Fig. 2). cDNA was synthesized using the pyrE primer, B. caldolyticus total RNA as template, and reverse transcriptase. The resulting cDNA was phenol extracted and ethanol precipitated prior to amplification with the same two primers as above.

Enzyme assays. Exponentially growing cultures were harvested, washed and sonicated. Enzyme activities were measured in the crude sonicated extracts by published methods: aspartate transcarbamylase (Prescott \& Jones, 1969), orotidine monophosphate (OMP) decarboxylase (Jensen et al., 1982), orotate phosphoribosyltransferase (Paulus et al., 1982; Poulsen et al., 1983). The reaction temperature was $60^{\circ} \mathrm{C}$ and $37^{\circ} \mathrm{C}$ with $B$. caldolyticus and $B$. subtilis extracts, respectively. Protein concentrations were determined by the Lowry method with bovine serum albumin as a standard.

\section{RESULTS}

\section{Cloning of the pyr genes}

Genomic libraries were prepared by digesting $B$. caldolyticus DNA with various restriction endonucleases, and ligating the fragments into plasmid pUC19 digested with the same or a compatible endonuclease. The libraries were used to transform pyrimidine-requiring mutants of E. coli ( $c a r B, p y r B,-C,-D,-E$ and $-F$ ) to pyrimidine prototrophy at $42{ }^{\circ} \mathrm{C}$. Plasmids capable of complementing a specific pyrimidine mutation were subsequently tested for their ability to complement the remaining five $E$. coli pyrimidine biosynthesis mutations. The following five plasmids were obtained from such screenings (Fig. 1a): pSY4 (BamHI library), pSY5 (SphI library), pSY6 (HindIII library), and PSY15 and -16 (partial Sau3AI library). The complementation pattern and the restriction map of these plasmids and of the four subclones PPM4, pPM15, pSY10 and pSY18 (Fig. 1a) showed that the six pyrimidine biosynthesis genes of $B$. caldolyticus are clustered on the chromosome, and that they are organized in the following order: $p y r B-p y r C$ - $p y r A-p y r D$-pyrF-pyrE.

\section{Expression of the pyr genes in B. subtilis}

To test for the presence of Gram-positive promoters within the region, segments containing $\operatorname{pyr} B-C, \operatorname{pyr} A$, $\operatorname{pyr} D$ and $\operatorname{pyr} F-E$, respectively, were cloned in both orientations in the E. coli/B. subtilis shuttle vector pHPS9, and the ability of the resulting plasmids to complement individual B. subtilis pyr mutations was determined (Fig. 1b). Plasmid pHPS9 contains a strong Lactococcus lactis promoter, $\mathrm{P} 59$, reading into the multiple cloning region. The copy number of pHPS9 in E. coli is very high, whereas it is only five to six in B. subtilis (Haima $e t$ al., 1990a). Since complementation was only observed with the fragments in one orientation, it was concluded that expression was dependent on transcription from the P59 promoter present on the vector. This further suggested that the genes are organized in an operon transcribed in the direction from pyrB towards pyrE.

\section{Nucleotide sequence}

The nucleotide sequence of a $10932 \mathrm{bp}$ region was determined on both strands and across all cloning junctions (Fig. 2). Computer assisted search of the sequence revealed the presence of nine open reading frames (ORFs). The $5^{\prime}$ end of the first ORF was not present on any of the clones. Based on the assumption that the $3^{\prime}$ end of $B$. caldolyticus $16 \mathrm{~S}$ rRNA is similar to that of B. subtilis and B. stearothermophilus 16S rRNA, i.e. 3' UCUUUCCUCCACUAG (Douthwaite et al., 1983; McLaughlin et al., 1981), putative ribosomal binding sites were located 7-11 bp upstream of the start codons of the first seven fully sequenced ORFs. For the last ORF the only sequence resembling a ribosomal binding site was located $66 \mathrm{bp}$ upstream of the putative start codon. The first two ORFs and the last two ORFs are separated by $169 \mathrm{bp}$ and $384 \mathrm{bp}$, respectively. The remaining ORFs are overlapping or, in one case, separated by 2 bp (Fig. 2).

\section{Identification of the ORFs}

The organization of the pyrimidine genes (Fig. 1) and the corresponding ORFs (Fig. 2) indicated great similarities with the pyr operon of B. subtilis (Quinn et al., 1991). Comparison of the deduced amino acid sequences of the eight fully sequenced ORFs from $B$. caldolyticus with those of the known $\mathrm{Pyr}$ proteins of $B$. subtilis revealed between 49 and $78 \%$ identity. This identified seven of the ORFs as subunits of the pyrimidine biosynthesis enzymes (Table 2). One major organizational difference between the $p y r$ clusters of the two organisms was that the coding regions of B. caldolyticus pyrF and pyrE appeared to be separated by a 384 bp non-translated region whereas the two cistrons overlap by $4 \mathrm{bp}$ in $B$. subtilis. To ascertain that this difference was not the result of a cloning artefact this region of the $B$. caldolyticus chromosome was amplified by PCR using a primer late in the pyrF gene and one early in the pyrE gene. The reaction yielded a $523 \mathrm{bp}$ fragment with a restriction endonuclease digestion pattern in accordance with the nucleotide sequence of the intercistronic region (Fig. 2). An identical 523 bp fragment was obtained by PCR amplification of B. caldolyticus $\mathrm{CDNA}$ using the same primers. The cDNA was derived from total $B$. caldolyticus RNA by reverse transcription using the early pyrE primer. This further indicated that the $B$. caldolyticus pyr $\mathrm{F} /$ pyrE intercistronic region is transcribed. 
(a)

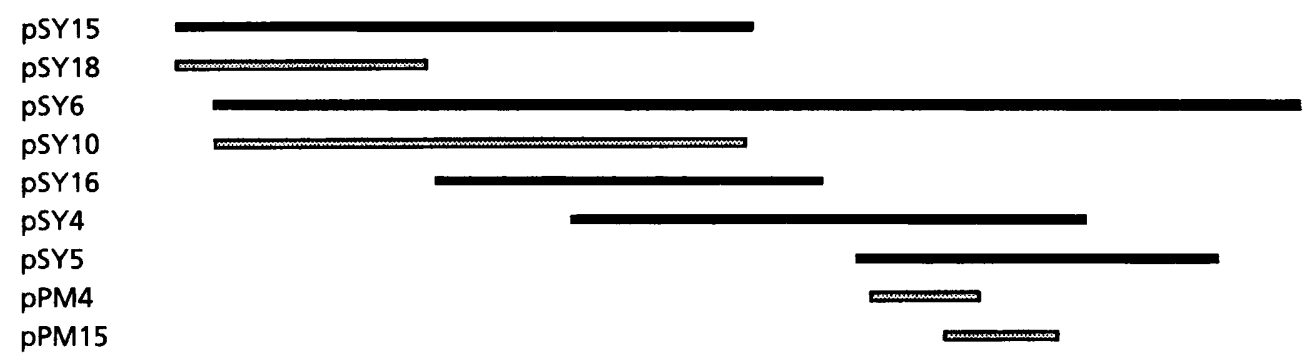

\section{Phenotype}

PyrB PyrC CarB PyrD PyrF PyrE

$+++$

$++$

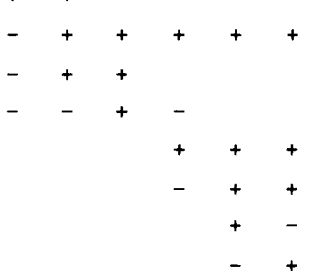

(b)
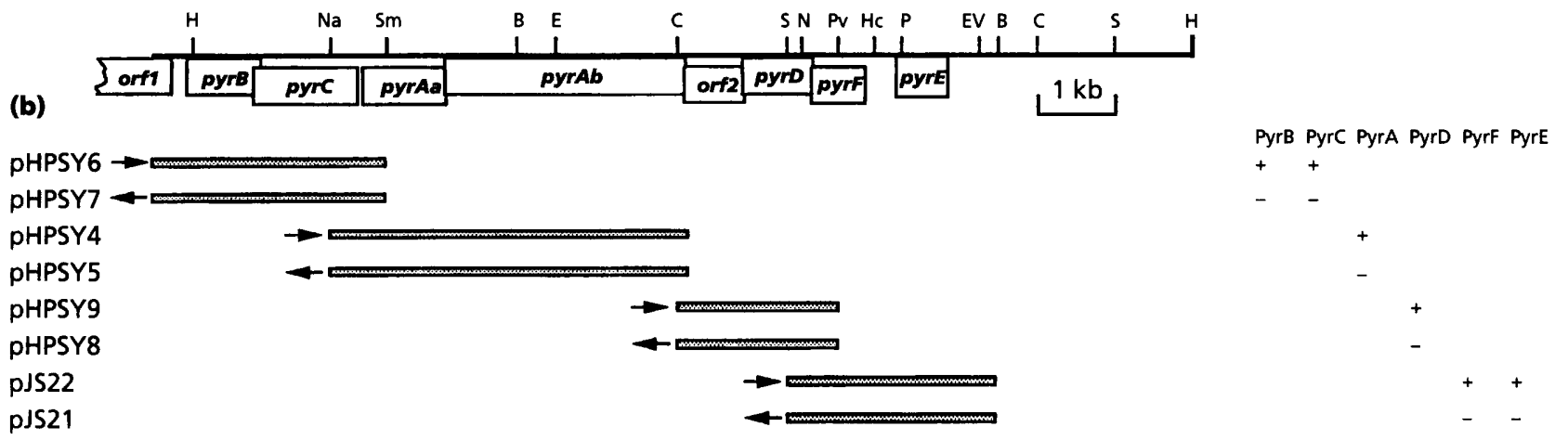

Fig. 1. Organization of the pyr gene-cluster of $B$. caldolyticus. Complementation by different DNA fragments of individual pyr mutations in $E$. coli (a) and B. subtilis (b). Filled bars indicate fragments obtained from the various libraries by complementation; hatched bars indicate fragments obtained by subcloning as described in Table 1 . The vectors used were pUC18/19 for the pSY and PPM plasmids, and pHPS9 for the pHPSY plasmids. In all the pUC-derived constructs the lac promoter of the vector promotes transcription of the fragments from left to right. The orientation of the vectorborne P59 promoter is indicated by arrows. CarB is the gene encoding the large subunit of carbamoylphosphate synthase of $E$. coli. It corresponds to the pyrAb gene of $B$. caldolyticus. The construction of the plasmids in Fig. 1 (b) is described in Table 1. Restriction endonuclease sites are abbreviated as follows: B, BamHI; C, Clal; E, EcoRI; EV, EcoRV; H, HindIII; HC, Hincll; N, Nsil; Na, Narl; P, Pstl; Pv, Pvull; S, Sphl; Sm, Smal.

\section{Codon usage}

A $\mathrm{mol} \% \mathrm{G}+\mathrm{C}$ of 59 was calculated for the protein coding regions of the B. caldolyticus pyr cluster (3181 codons). This is considerably higher than found for the homologous regions of $B$. subtilis (Table 3 ). In particular the third codon position showed a strong bias for $\mathrm{G}$ or $\mathrm{C}$ $(73 \%)$, as has been observed for protein coding regions of other organisms with high $\mathrm{G}+\mathrm{C}$ content (Kagawa et al., 1984; Kimsey \& Kaiser, 1992). This strong bias is particularly pronounced with the Val, Ser, Pro, Thr, Ala, Cys, Arg and Gly codons where 84 to $91 \%$ of them end with $G$ or $C$ (Table 4).

\section{Transcription signals}

Two regions of partial dyad symmetry were located within the untranslated region between orf1 and $p y r B$. A transcript of this region may form two competing secondary structures. One, located at positions 335-360, resembled a Rho-independent transcriptional terminator consisting of a GC-rich stem-loop structure followed by 8
U-residues (Fig. 3a). The stability of this hairpin was calculated to be $-90 \mathrm{~kJ} \mathrm{~mol}^{-1}$. The other structure is located between positions 268 and 341. This large and more stable structure $\left(\Delta G=-215 \mathrm{~kJ} \mathrm{~mol}^{-1}\right)$ includes most of the left stem of the terminator hairpin (Fig. 3a). In addition, a region of partial dyad symmetry showing some resemblance to a Rho-independent transcriptional terminator was located $15 \mathrm{bp}$ downstream of the last gene of the cluster (pyrE).

\section{Pyrimidine regulation of pyr gene expression}

The specific activity of aspartate transcarbamylase ( $p y r B)$, orotate phosphoribosyltransferase ( $p y r E$ ), and OMP decarboxylase $(p y r F)$ was determined in crude sonicated extracts of $B$. caldolyticus grown exponentially at $60^{\circ} \mathrm{C}$ in minimal medium with or without uracil $\left(20 \mu \mathrm{g} \mathrm{ml}^{-1}\right)$. For comparison, the activity of two of the enzymes was also determined in extracts of $B$. subtilis grown in similar conditions at $37^{\circ} \mathrm{C}$. As shown in Table 5, addition of uracil resulted in 7-9-fold repression of pyrB, pyrE and pyrF expression in B. caldolyticus. Regulation of the two $B$. subtilis enzymes assayed occurred to the same extent. 
GATCGACA GCCGCGTCGATRCGGCCA GACGCCCAATTAGTCATCGCCTCGGTCATCTTG GTCATCGGCATCGGCGGAGCGGTCCTGAAAATCAGCGACAGCTTCCAATTACCGGGAT

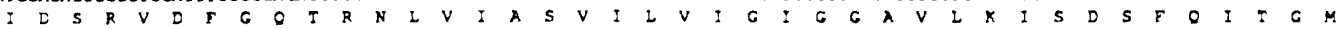

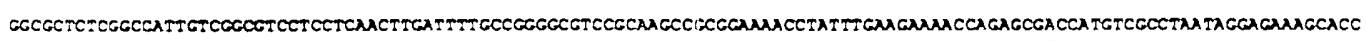
A L S A I V G V L L L N L L I L Antiterminator

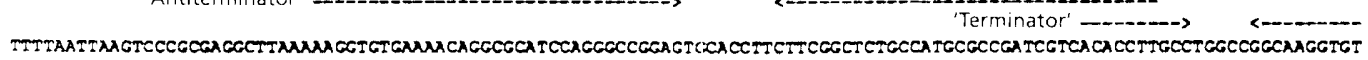
RBS PyrB -->

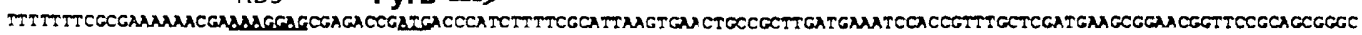

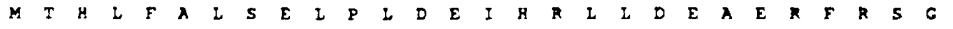

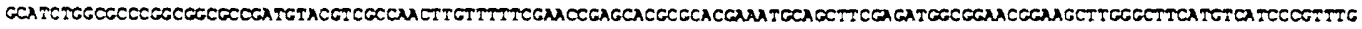

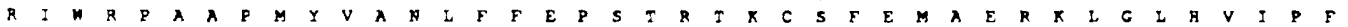
ACCCGQAACGCTCGACCOTCCAMAMGGGGA GACGCTGTACGATACCGTACGGACGCTTGAGGCGATCGOCGTCGATCCGGTTGTOATCCGCCATCACGAMGATGCGTATTTCGAMGCGC

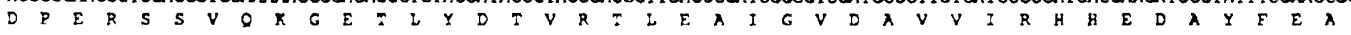

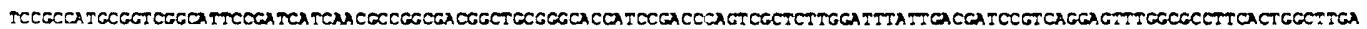
I R H A V G I P I I A A G D G C G H H P T O S L L D I L I I R O E F G A F I G L

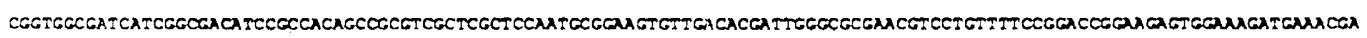
I V A I I G D I R H S R V A R S N A E V L T R L G A N V L $F$ S

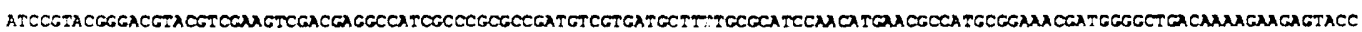

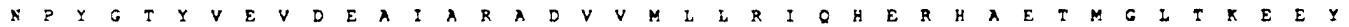

-... - - - - -

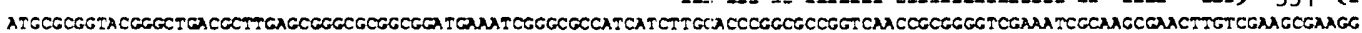

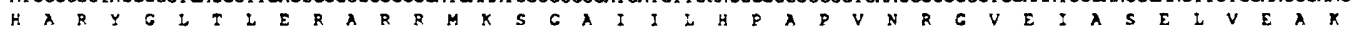

$$
\text { RBS PyrC } \rightarrow
$$

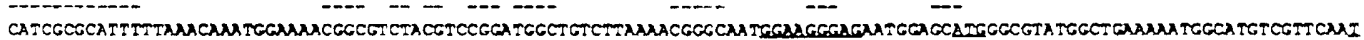

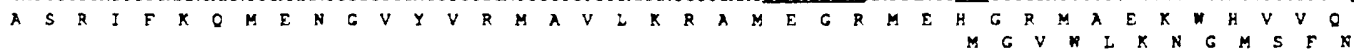

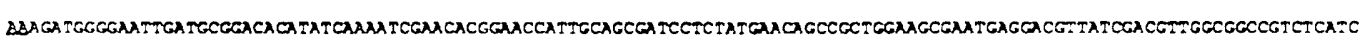
K D G E L M R T G I K I E H G T I A A I I Y E GTTCCTGGCCTGA TCGACTTGCACGTTCATTTGCGCGAACCGGGCGGCQAAGCGAAGAAACGATTGAAACGGGCACGCTCGCCGCGGCGAAAGGCGGATTTACGACGGTTGCTGCCATG $V P G I$ I D L H V H

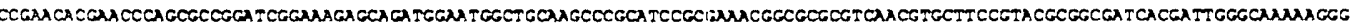

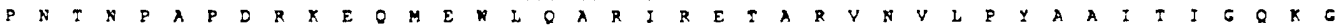

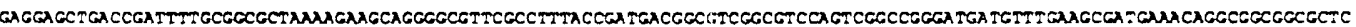

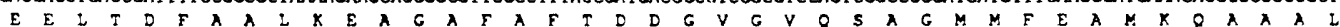

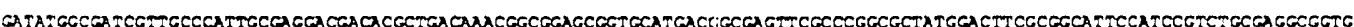

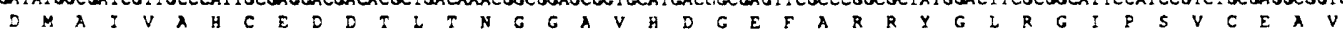

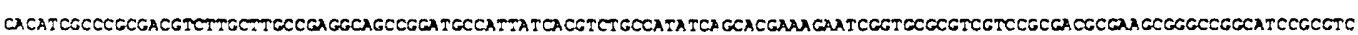
H: A R D V L L A E A A G C A Y ACCGCCGAAGTGACGCCGCACCATCTCCTCTTGTGCGATGAGGATATTCCAGGGCTTGATGCGAACTACAAAATGAACCCACCGCTGCGCAGCCGAGAGGACCGTGACGCATIAATTGAA I A E $E$ V $T$ I GGACT GCTCGACGCCACGATCGACTTTATCGCCACGGACCACGCGCCGOATACOGCTGCCGMAAAGCCGMAGGOATCGA GGCGGCGCCGTTT GOCATCGTTGGGCTCGAAACGGCGTTT

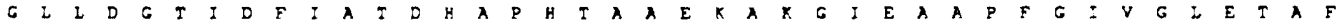

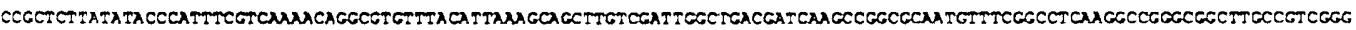

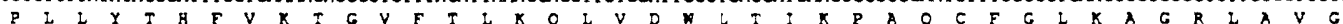

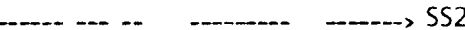
GCGCCGGCGGATATTGCGGTCATTGATTTGGAMCAGMGMGCCATTCATCCCGACAOCTTTGLOTCCAAAGGGAAAATACGCCGTTTCCCGGCTGGGTGTGCCAAGGCTGGCCGGTG 2520

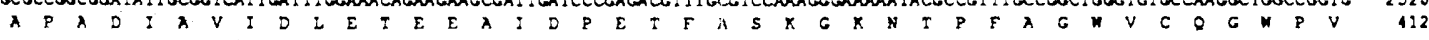

$$
\text { RBS PyrAa ---> }
$$

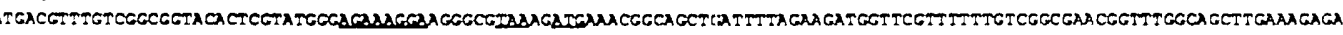
$M T F$ V G G T L V $E \times G R \times$

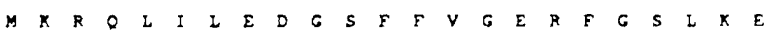

CGACCGGGGA $T=G E V V F$ T G M T G Y O E I L S D P S Y C G Q I V T M I Y P I I G N Y G I

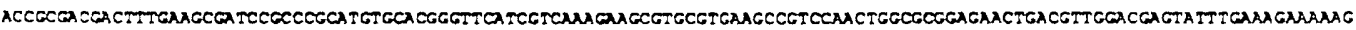
$N R$ D D F E A I R P H V H G F I V K E A C V K P S N W A G E

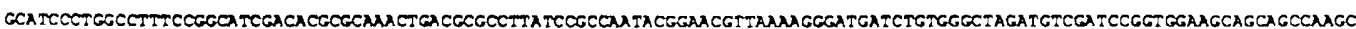

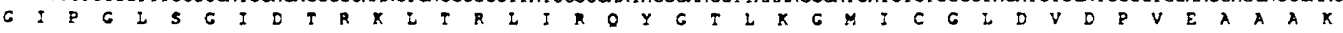

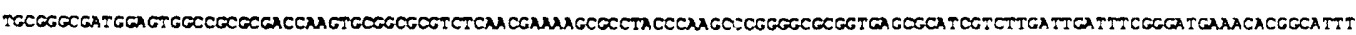
L R A E P R D Q V R R V S T K S A Y P S R G R G E R I V L I D F G M X H G I TGCGCGAACTGANCA GCGAMATTGCGATGTGATCGTCTTCCCCTACAACGCCACCGCTGMAGAGOTGCTCGGCTGGCATCCGGATGGCGTCATGCT:TCCAATGGACCGGGCGACCCGA

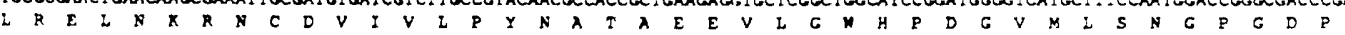
MGGACGGCCGGAAGCG TCGAGATGATCCGCGGGATTCTCGGCAMAGTGCCGCTCTTTGGCATCTGCCTCGGCCATCAGCTGTTCGCGTTGGCGTGCGGCGCGAATACCGAGAAAATGA

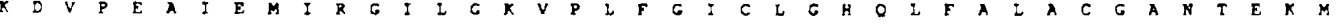

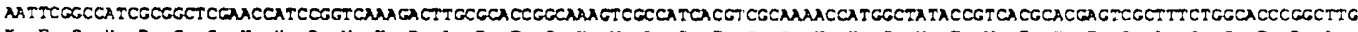

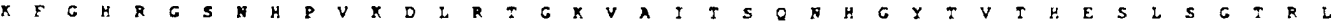

220

210

360

4

Fig. 2. For legend see p. 487. 


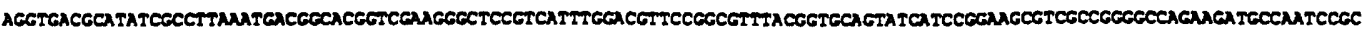
E V I H I A L D D G T V E G L R H L D V P A F I V Q Y H P E A S P G P E D A N P RBS PyrAB $\rightarrow$

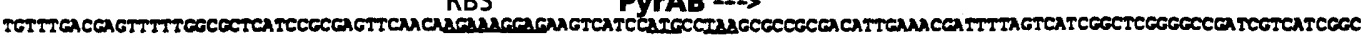
L F D F L A I I R E F M K X G E V I H A.

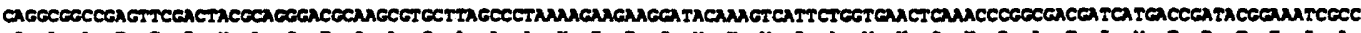
D A A E F D Y A G I O A C L A I K E E G Y K V I L V X S I I P A I I M I D I E I A

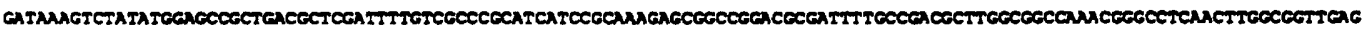

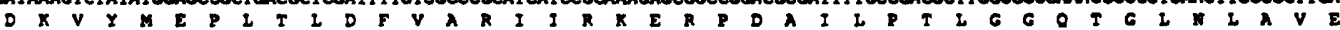

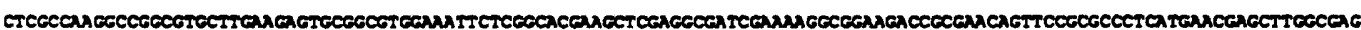
LAKA G V L E E C C V E I L G T K L E A I E KA E D RE O F R A L M I E L G E

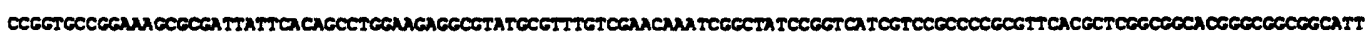
P V P S A I I A S LE E A Y A F V E O I G Y P V I V R P A F I L G G I G G G I

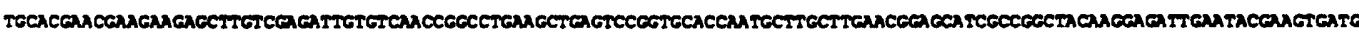
C I E E E L V E I V S T G L R L S P V H O C L L E R S I A G Y K E I E Y E V M

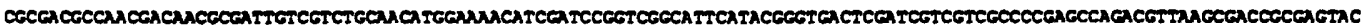

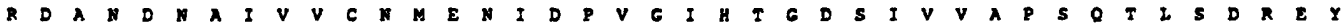

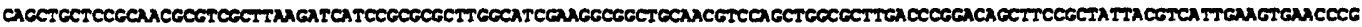
Q I L R A S L K I I R A I G I E G G C N V O L A L D P D

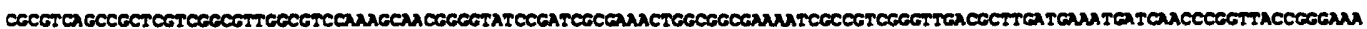

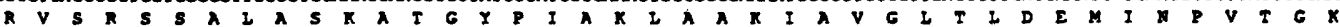

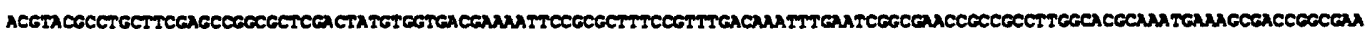

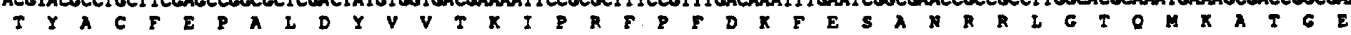

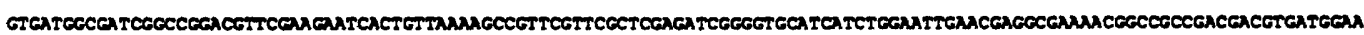
V M I G R T E E S L L R A V R S L E I G V H H I E L N E A K T A A D D V M E

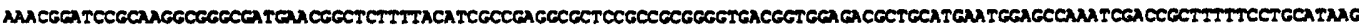
K R I R K A G D E R L F Y I A E A L R R G V T V E I I A E N

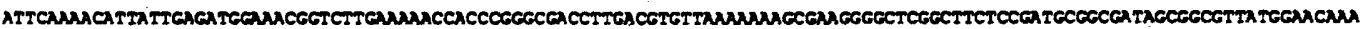
I

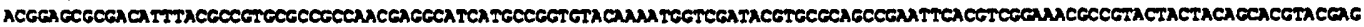

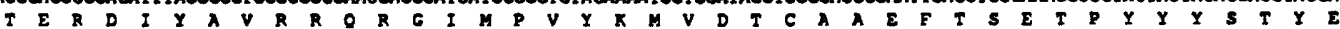

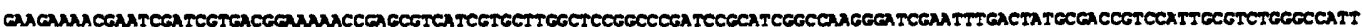

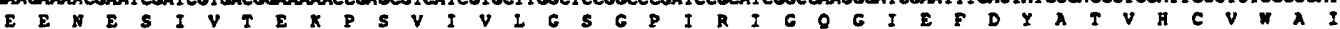

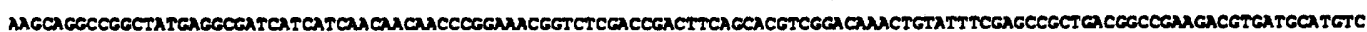

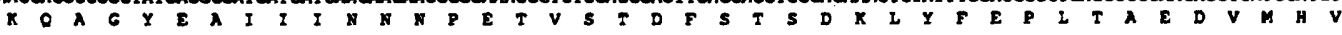

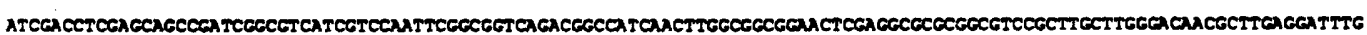
I D L E O P I G V I V O F G G O I A I X L A A E L E A R G V R L L G T I L E D L

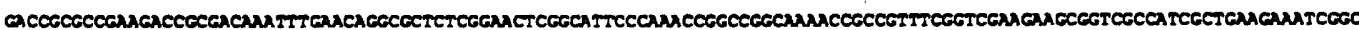
$D R A E D R$ D K F E O A L S E I G I P K P A G K T A V S V E E A V A I A E E I G

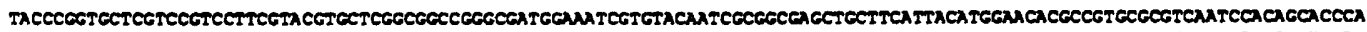
Y P V

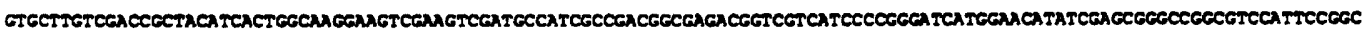
V I V D R Y I T G K E V E V D A I A D G E T V V I P G I M E A I E RAG G H S G

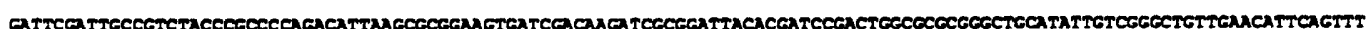
D S I A V Y P P O I I S A E V I D K I A D Y I I R L A R G I

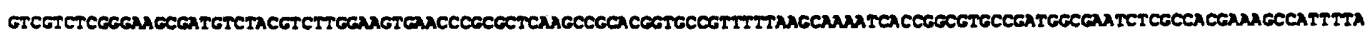
$V$ V S G S D V Y V L E V R P R S S R T V P F L S K I T G V P M A N L A T K A I I GGAcen G I K L A E M G Y E T G V C P V R P G V Y V X V P V F S F A R I R N V D I S I G

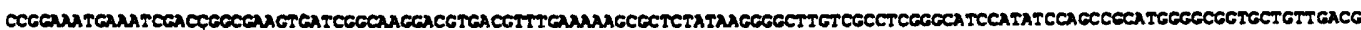

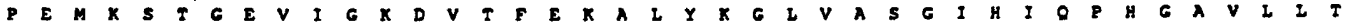

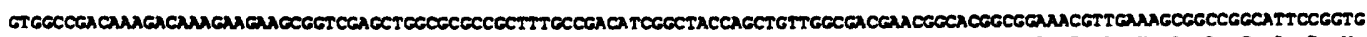

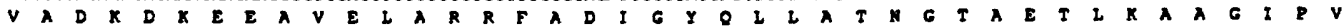

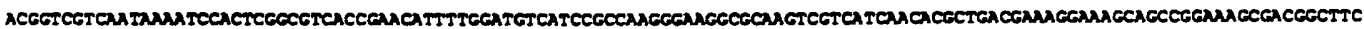
T $Y$ S RBS

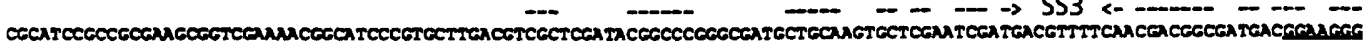

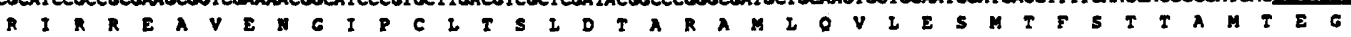
Orf2 -->

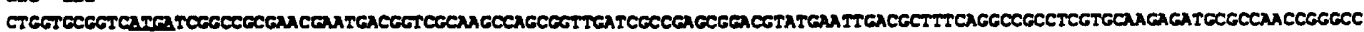
I $V R S$ A I G E R I I V A S O R I I A E R I Y E I I I S G R L V O E Y R O P G

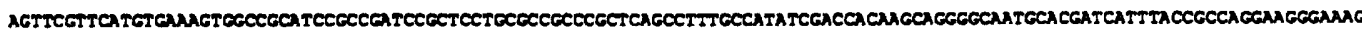

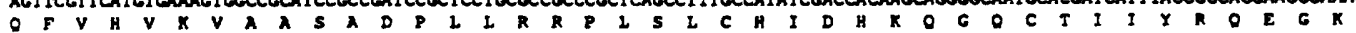




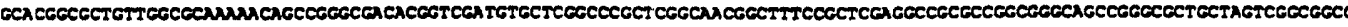
C I A L I A Q R Q P G D T V D V L G P L G O G F P I E A A P A G S A A I I V G G

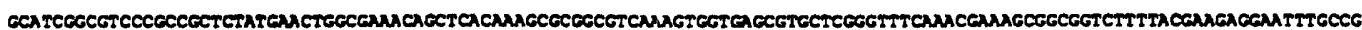
G I G V P P I Y E L A K O L T K R G V K V V S V L G F T T K A A V F Y E E E F A

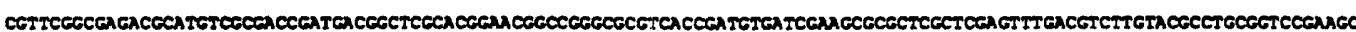
A F E I I V A T D D G S H G T A G R V T D V I E A R S I E F D V L Y A C G P K

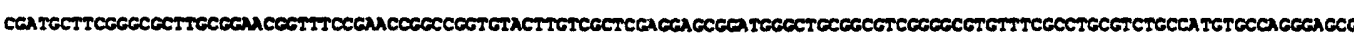

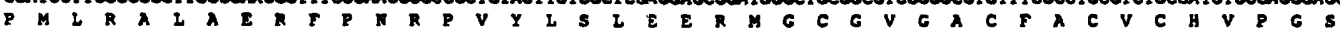
$\longrightarrow$ SS4 RBS PyrD $\rightarrow$

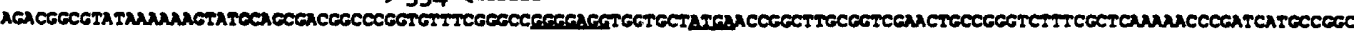

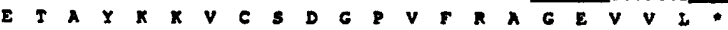
M R L A V E L P G L S L K P I M P A

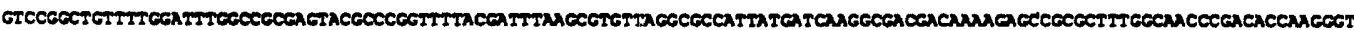

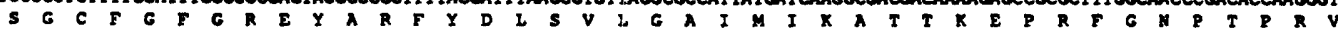

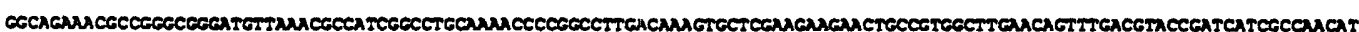
A E T P G G M L N A I G L O N P G L D K V L E E E L P W L E

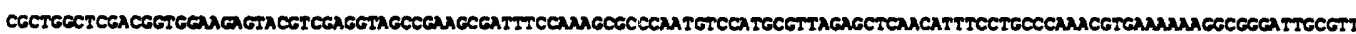

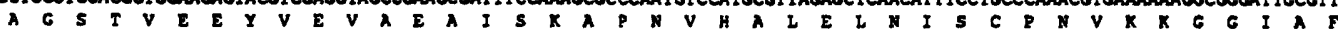

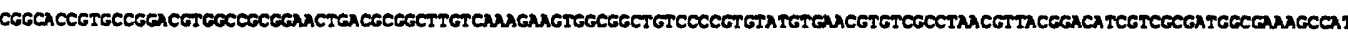
C I V P D V A A E I I R I V K E V A A V P V Y V V V S P

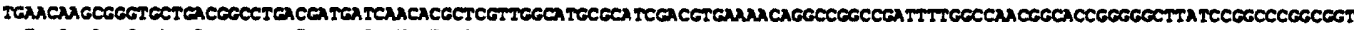

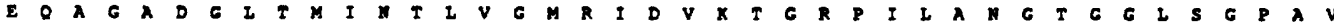

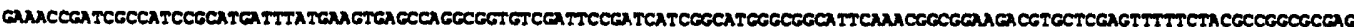
$X$ P I A I M I Y E V S Q A V S I P I I G A G G O I A E D V L E F F Y A A S

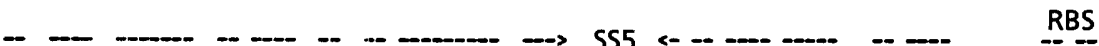

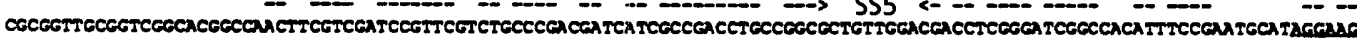

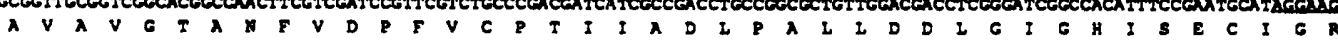
PyrF $\rightarrow-\rightarrow$

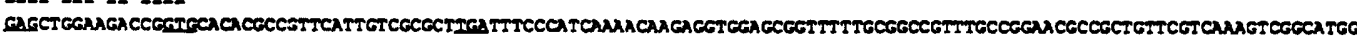

$S$ N $K$ T $G$ A H A V H C R A .

M H I P F I V A L D F P

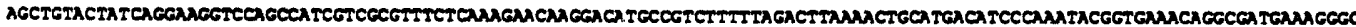

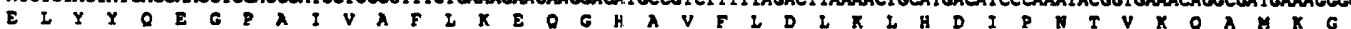

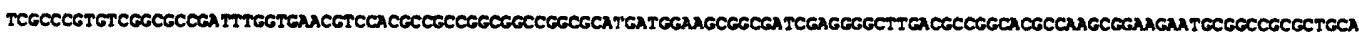
L A R G A D L V R V H A A G G R R M M E A A I E G L D A G T P S G R M R R R C

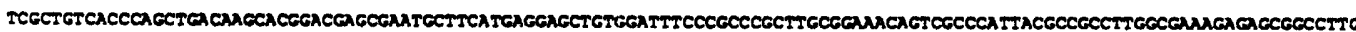
I A V T O L T S T DE R M L H E E L W I S R P L A E T V A H Y A A L A K E S G L

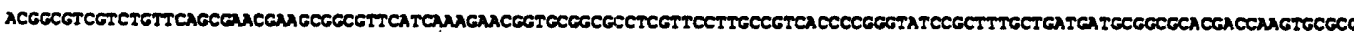
D G V V C S A E A A F I K E R C G A S F I A V T P G I A F A D D A A H D O V R pyrF primer

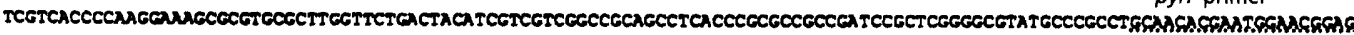
V V V I $P$ P $R$ X A A R A L

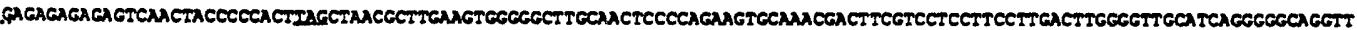
$G E R E S T T P T$.

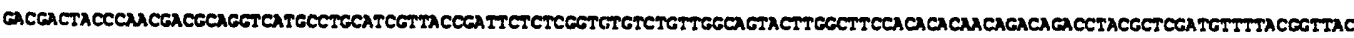

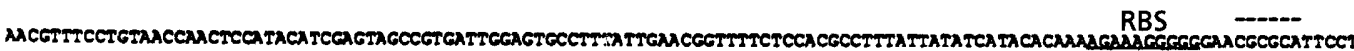

7200

216

7320

156

7440

196

7560

236

7600

257
20

7800

60

7920

100

8040

140

8160

100

8280

220

8400

260

0520

300

9640

313

0760

75

8680

125

9000

155

9120

195

9240

235

9360

244

9480

9600

Pyre -->

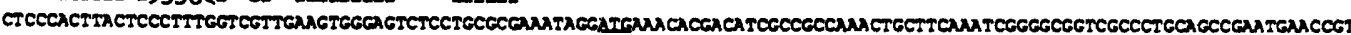
pyre primer

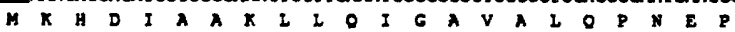

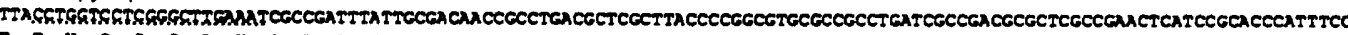
F I I S S G I X S P I Y C D N R L T L A Y P G V R R I I A D A I A E L I R I H F

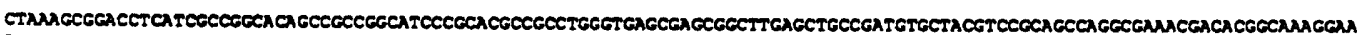
P K A D L I A G I A G I P A A A R V S E R L E I P M C Y V R S O A K R G K G $X$ I E G Q A R G G R V V V I

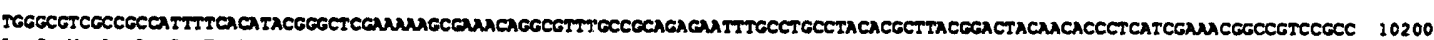
L G V A A I

$$
\text { terminator }
$$

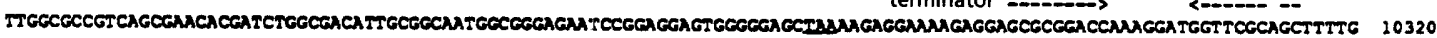

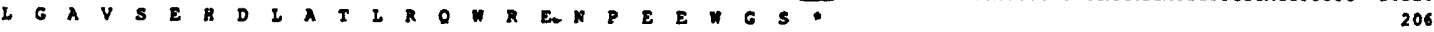

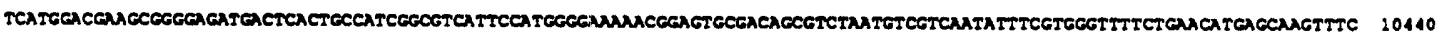

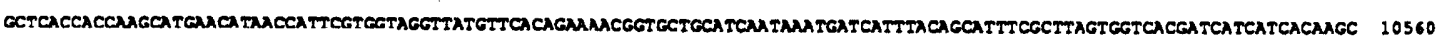




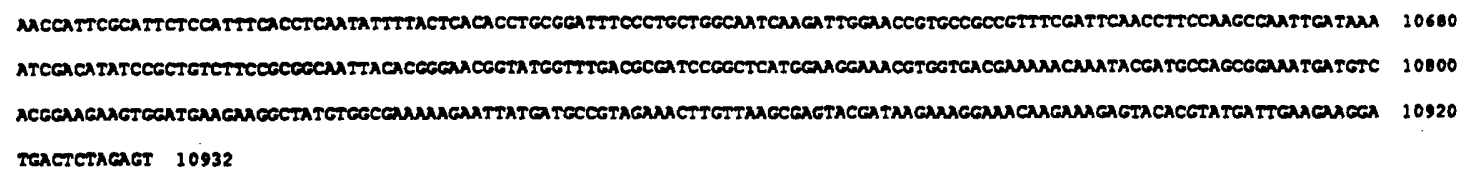

TeActetacact 10932

Fig. 2. Nucleotide sequence of the $B$. caldolyticus pyrimidine biosynthesis gene-cluster. Below the sequence the deduced amino acid sequence is given in the one-letter code. Start and stop codons of the coding regions as well as putative ribosomal binding sites are underlined. Broken arrows above the sequence indicate regions of dyad symmetry (SS1 to SS6). The positions of the PCR primers employed are indicated by dotted underlines.

Table 2. B. caldolyticus pyr gene-enzyme correlations

Genes are listed in their order on the chromosome in the direction of transcription. All data are based on amino acid sequences deduced from the DNA sequences.

\begin{tabular}{|c|c|c|c|c|c|}
\hline \multirow[t]{2}{*}{ Gene } & \multirow[t]{2}{*}{ Enzyme } & \multirow[t]{2}{*}{$\begin{array}{l}\text { Amino } \\
\text { acids }\end{array}$} & \multirow[t]{2}{*}{$M_{\mathrm{r}}$} & \multicolumn{2}{|c|}{$\begin{array}{l}\text { Amino acid identity }(\%) \text { with } \\
\text { corresponding gene products } \\
\text { from:* }\end{array}$} \\
\hline & & & & B. subtilis & E. coli \\
\hline pyrB & Aspartate transcarbamylase & 308 & 34871 & $61(304)$ & $31(310)$ \\
\hline pyrC & Dihydroorotase & 427 & 46047 & $65(428)$ & $21(348)$ \\
\hline pyr $A a$ & $\begin{array}{l}\text { Carbamoylphosphate synthetase } \\
\text { (glutaminase subunit) }\end{array}$ & 364 & 40289 & $73(364)$ & $42(380)$ \\
\hline pyr $A b$ & $\begin{array}{l}\text { Carbamoylphosphate synthetase } \\
\text { (catalytic subunit) }\end{array}$ & 1065 & 116482 & $78(1071)$ & $49(1072)$ \\
\hline orf 2 & Unknown function & 257 & 27641 & $57(256)$ & \\
\hline pyrD & Dihydroorotate dehydrogenase & 313 & 32857 & $76(311)$ & $17(336)$ \\
\hline$p y r F$ & OMP decarboxylase & 244 & 26547 & $49(239)$ & $31(245)$ \\
\hline pyrE & Orotate phosphoribosyltransferase & 206 & 22401 & $58(210)$ & $16(238)$ \\
\hline
\end{tabular}

* Numbers in parentheses indicate number of amino acids in the polypeptide.

Table 3. DNA base composition of pyrimidine biosynthesis genes from $B$. caldolyticus and $B$. subtilis

\begin{tabular}{|c|c|c|c|c|c|}
\hline \multirow[t]{2}{*}{ Organism } & \multicolumn{4}{|c|}{$\begin{array}{c}\text { Mol } \% \mathrm{G}+\mathrm{C} \text { at each codon } \\
\text { position }\end{array}$} & \multirow{2}{*}{$\begin{array}{c}\text { Mol } \% \text { G }+ \text { C } \\
\text { of whole } \\
\text { genome }\end{array}$} \\
\hline & 1 & 2 & 3 & Mean & \\
\hline B. caldolyticus & 62 & 42 & 73 & 59 & $53 \cdot 4 \dagger$ \\
\hline B. subtilis* & 59 & 38 & 45 & 47 & 42.95 \\
\hline
\end{tabular}

* From Quinn et al. (1991).

†From De Bartolomeo et al. (1991).

§From Fahmy et al. (1985).

\section{DISCUSSION}

The present paper describes the cloning and structural characterization of the pyr genes, encoding the six enzymes of pyrimidine biosynthesis, from the thermophile $B$. caldolyticus. Complementation studies in E. coli indicate that the genes are clustered within an $11 \mathrm{~kb}$ region. The nucleotide sequence of the cluster reveals the presence of nine cistrons of which eight are fully sequenced. The $5^{\prime}$ end of the first, ORF1, is not present on any of the cloned fragments. Comparison of the deduced amino acid sequences with the known Pyr proteins of $B$. subtilis and $E$. coli identifies seven of the ORFs as subunits of the six pyrimidine biosynthesis enzymes (Table 2). Furthermore, it shows that the first enzyme of the pathway, carbamoylphosphate synthetase ( $\operatorname{pyr} A$ ), is composed of two nonidentical subunits, like the $E$. coli and $B$. subtilis enzymes. So far no function has been assigned to ORF2, and a search in the protein databases revealed that the only protein with significant similarity was ORF2 of the $B$. subtilis pyr operon. The overall genetic organization of the B. caldolyticus pyr region, orf1-pyrB-pyrC-pyr $A a-p y r A b$ orf2-pyrD-pyrF-pyrE (Fig. 1), is the same as in B. subtilis (Quinn et al., 1991). The major difference is that the pyrF and pyrE cistrons are separated by 384 bp in B. caldolyticus, whereas they overlap with $4 \mathrm{bp}$ in B. subtilis.

The B. subtilis pyr cluster is organized as a single 
Table 4. Codon usage of pyrimidine biosynthesis genes from B. caldolyticus and B. subtilis

Bc, B. caldolyticus. Bs, B. subtilus (Quinn et al, 1991).

\begin{tabular}{|c|c|c|c|c|c|c|c|c|c|c|c|c|c|c|c|c|}
\hline \multirow[b]{2}{*}{$\begin{array}{l}\text { 1st } \\
\text { position }\end{array}$} & \multicolumn{16}{|c|}{ 2nd position } \\
\hline & & $\mathrm{J}$ & Bc & Bs & & C & Bc & Bs & A & & $\mathbf{B c}$ & Bs & C & ; & Bc & Bs \\
\hline \multirow[t]{4}{*}{$\mathbf{U}$} & Phe & UUU & 60 & 61 & Ser & UCU & 2 & 32 & Tyr & UAU & 29 & 54 & Cys & UGU & 6 & 21 \\
\hline & Phe & UUC & 44 & 43 & ser & UCC & 20 & 24 & Tyx & UAC & 54 & 36 & Cys & UGC & 39 & 25 \\
\hline & Leu & UUA & 25 & 57 & Ser & UCA & 12 & 48 & END & UAA & 4 & 3 & END & UGA & 3 & 4 \\
\hline & Leu & UUG & 60 & 41 & Ser & UCG & 48 & 15 & END & UAG & 1 & 1 & $\operatorname{Trp}$ & UGG & 23 & 15 \\
\hline \multirow[t]{4}{*}{ C } & Leu & CUU & 57 & 83 & Pro & $\mathrm{CCU}$ & 8 & 44 & His & CAU & 53 & 47 & Arg & $\mathrm{CGU}$ & 10 & 13 \\
\hline & Leu & cuc & 71 & 37 & Pro & $\mathrm{CCC}$ & 10 & 7 & His & CAC & 32 & 21 & Arg & CGC & 114 & 26 \\
\hline & Leu & CUA & 5 & 20 & Pro & $\mathrm{CCA}$ & 18 & 23 & Gln & CAA & 42 & 64 & Arg & CGA & 8 & 10 \\
\hline & Leu & CUG & 70 & 60 & Pro & $\mathrm{CCG}$ & 126 & 72 & Gln & CAG & 40 & 47 & Arg & CGG & 48 & 21 \\
\hline \multirow[t]{4}{*}{ A } & Ile & AUU & 58 & 102 & Thr & $\overline{A C U}$ & 4 & 17 & Asn & AAU & 20 & 60 & Ser & AGU & 2 & 13 \\
\hline & Ile & AUC & 148 & 105 & Thr & $A C C$ & 38 & 21 & Asn & AAC & 70 & 64 & Ser & AGC & 45 & 46 \\
\hline & Ile & AUA & 2 & 9 & Thr & ACA & 20 & 100 & Lys & AAA & 113 & 146 & Arg & AGA & 3 & 49 \\
\hline & Met & AUG & 77 & 78 & Thr & $\mathrm{ACG}$ & 126 & 52 & Lys & AAG & 33 & 54 & Arg & AGG & 4 & 7 \\
\hline \multirow[t]{4}{*}{$\mathbf{G}$} & Val & GUOU & 19 & 54 & Ala & GCU & 14 & 62 & Asp & GAU & 45 & 87 & Gly & GGU & 12 & 41 \\
\hline & Val & GUC & 144 & 75 & Ala & GCC & 126 & 37 & Asp & GAC & 92 & 65 & Gly & GGC & 174 & 77 \\
\hline & Val & GUA & 6 & 61 & Ala & GCA & 19 & 86 & Glu & GAA & 159 & 197 & Gly & GGA & 25 & 89 \\
\hline & Val & GUG & 101 & 62 & Ala & GCG & 175 & 86 & Glu & GAG & 99 & 75 & Gly & GGG & 66 & 42 \\
\hline
\end{tabular}

(a)

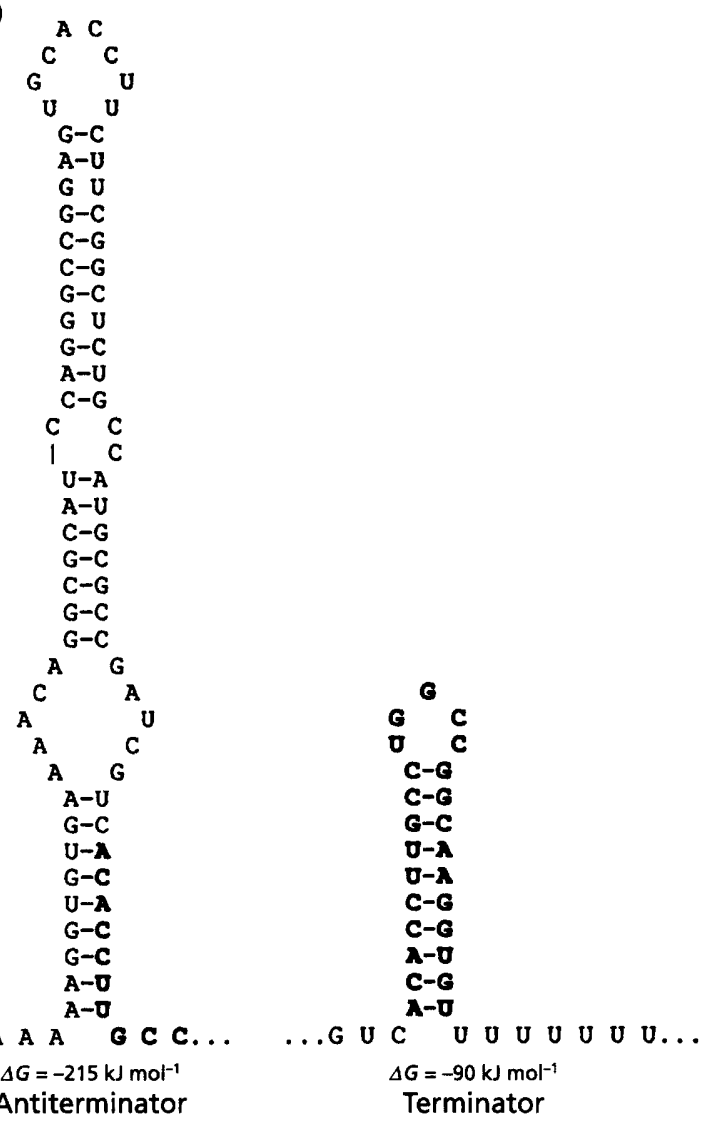

(b)

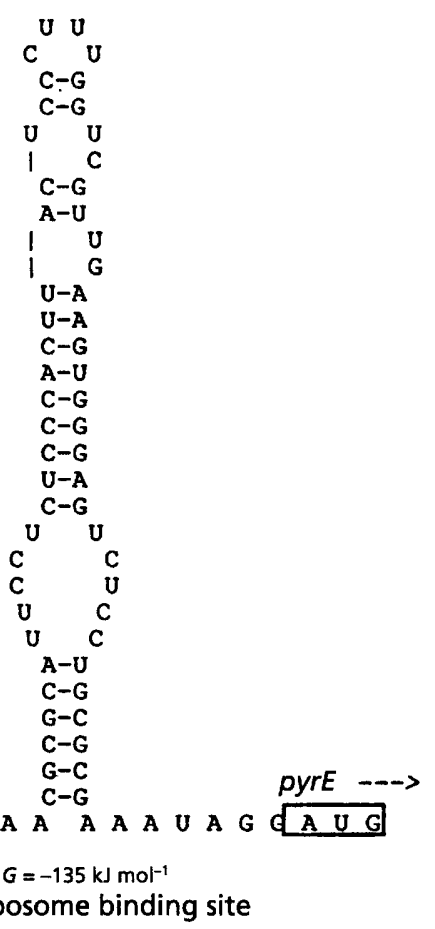

Fig. 3. Potential secondary structures of the intercistronic transcripts. (a) Mutually exclusive antiterminator and terminator structures of the orf1-pyrB intercistronic region. Bold letters represent bases overlapping in the two structures. (b) Putative ribosomal binding site for pyrE in the pyrf-pyrE intercistronic region. 
Table 5. Pyrimidine biosynthesis enzyme activities in $B$. caldolyticus and $B$. subtilis

Cells were grown exponentially in minimal medium with uracil $\left(20 \mu \mathrm{g} \mathrm{m}^{-1}\right)$ or without uracil at $60^{\circ} \mathrm{C}$ for B. caldolyticus and at $37^{\circ} \mathrm{C}$ for B. subtilis.

\begin{tabular}{|lcccc|}
\hline Organism & $\begin{array}{c}\text { Growth } \\
\text { condition }\end{array}$ & \multicolumn{3}{c|}{ Specific activity* } \\
\cline { 3 - 5 } & & $\begin{array}{c}\text { ATCase } \\
(p y r B)\end{array}$ & $\begin{array}{c}\text { OPRTase } \\
(p y r E)\end{array}$ & $\begin{array}{c}\text { OMP } \\
\text { decase } \\
(p y r F)\end{array}$ \\
\hline B. caldolyticus & -Uracil & $9 \cdot 9$ & $30 \cdot 7$ & $13 \cdot 2$ \\
& +Uracil & $1 \cdot 5$ & $3 \cdot 5$ & $1 \cdot 4$ \\
B. subtilis & - Uracil & 86 & ND & $17 \cdot 1$ \\
& +Uracil & $7 \cdot 0$ & ND & $2 \cdot 3$ \\
\hline
\end{tabular}

* Specific activities are $\mathrm{nmol} \mathrm{min}^{-1}(\mathrm{mg} \text { protein })^{-1}$. A'TCase, aspartate transcarbamylase; OPRTase, orotate phosphoribosyltransferase; OMP decase, OMP decarboxylase. B. caldolyticus extracts were assayed at $60^{\circ} \mathrm{C}$ and $B$. subtilis extracts at $37^{\circ} \mathrm{C}$. Assays were done in duplicate and the values represent the mean of two assays having less than $20 \%$ variance. ND, Not determined.

transcriptional unit with the promoter located upstream of the orf1 gene (Quinn et al., 1991). Two lines of evidence suggest that this is also the case in B. caldolyticus. Firstly, expression of the cloned $B$. caldolyticus pyr genes in $B$. subtilis is dependent on the presence of the P59 promoter located on the vector (Fig. 1b). Secondly, most of the cistrons within the cluster are overlapping. It should be noted that we have not obtained clones containing the entire orf 1 gene and the putative promoter region from any of our pUC-based libraries. This may be related to the observation that plasmids containing the pyr promoter and orf1 of B. subtilis are unstable in $E$. coli unless the plasmid copy number is reduced (Quinn et al., 1991).

Shortly downstream of the last gene in the cluster (pyrE) the nucleotide sequence indicates a region of hyphenated dyad symmetry followed by a series of T-residues. This may represent the transcriptional terminator of the operon.

A common feature of several B. subtilis biosynthetic operons, including the trp, pur and pyr operons, is that they contain overlapping cistrons (Ebbole \& Zalkin, 1987; Henner et al., 1984; Quinn et al., 1991). A similar organization is observed for most of the cistrons in the B. caldolyticus pyr cluster. Overlapping reading frames may indicate that the genes in question are translationally coupled, i.e. the translational efficiency of one gene in an operon is determined by the translational efficiency of the adjacent upstream gene (Gold, 1988; Oppenheim \& Yanofsky, 1980). The observation that transcripts of the junctions between the five overlapping gene-pairs, $p y r B /$ pyrC, pyrC/pyrAa, pyr $A b / \operatorname{orf} 2$, orf $2 /$ pyrD and pyrD/ pyrF, have the potential to form stable secondary structures sequestering the ribosomal binding regions of the downstream genes (indicated by SS1 to SS5 on Fig. 2) suggests that translational coupling may play a role in expression of the $B$. caldolyticus pyr genes. The stability of the secondary structures (in k J mol${ }^{-1}$ ) is calculated to be $-228,-163,-128,-85$ and -208 respectively. Thus, translational initiation may be inefficient unless formation of the secondary structure on the transcript in the junction region is precluded by ribosomes translating the $3^{\prime}$ end of the upstream gene.

The nucleotide sequence of the $p y r F-p y r E$ intercistronic region does not indicate a ribosomal binding site immediately $5^{\prime}$ of the pyrE start codon. However, a good Shine-Dalgarno sequence is found $66 \mathrm{bp}$ upstream of the pyrE start codon at positions 9576 to 9585 . The transcript between this putative strong ribosomal binding site and the start codon has the potential to form a stable hairpin with a $\Delta G$ of $-133 \mathrm{~kJ} \mathrm{~mol}^{-1}$ (SS6 on Fig. 2 and Fig. 3b), which may permit the upstream Shine-Dalgarno sequence to function as an efficient ribosomal binding site for pyrE. A ribosomal binding site including a secondary structure has previously been found in gene 38 of the E. coli bacteriophage T4 (Gold, 1988; Tuerk et al., 1988). It was proposed that the mRNA is positioned on the $30 \mathrm{~S}$ subunit such that the hairpin protrudes into the solvent, and hence does not interfere with binding of the 50S subunit (Gold, 1988).

The specific activities of aspartate transcarbamylase $($ pyrB), orotate phosphoribosyltransferase (pyrE) and OMP decarboxylase $(p y r F)$ in extracts of $B$. caldolyticus are decreased in cells grown with uracil in the medium. This indicates that expression of the pyr operon is negatively regulated by pyrimidines in much the same way as the pyr operon of B. subtilis (Paulus et al., 1982; Table 5). Inspection of the nucleotide sequence in the intercistronic region upstream of $p y r B$ shows that the transcript of that region may form two mutually exclusive stem and loop structures of which the most distal resembles a factorindependent transcriptional terminator. The proximal structure precludes the terminator hairpin from forming and may therefore act as an antiterminator (Fig. 3a). Since the homologous region of the $B$. subtilis pyr operon encodes a transcript with the potential to form similar secondary structures, we propose that these structures are involved in pyrimidine control of the pyr operon, and that regulation involves transcriptional termination and antitermination by a mechanism similar to the one shown to be involved in the control of trp operon and pur operon expression in B. subtilis (Babitzke \& Yanofsky, 1993; Kuroda et al., 1988; Zalkin \& Ebbole, 1988).

\section{ACKNOWLEDGEMENTS}

We would like to thank Lisbeth Stauning for expert technical assistance, Steffen Danielsen for help with the computer searches, M. Schwartz for introducing us to the PCR technique, R. A. Kelln for the gift of synthetic oligomers, and Mogens Kilstrup and Kim Sorensen for comments to the manuscript. This work was supported by the Danish Centre of Microbiology. 


\section{REFERENCES}

Asahi, S., Doi, M., Tsunemi, Y. \& Akiyame, S. (1989). Regulation of pyrimidine nucleotide biosynthesis in cytidine deaminase-negative mutants of Bacillus subtilis. Agric Biol Cbem 53, 97-102.

Babitzke, P. \& Yanofsky, C. (1993). Reconstitution of Bacillus subtilis trp attenuation in vitro with TRAP, the $\operatorname{tr} p$ RNA-binding attenuation protein. Proc Natl Acad Sci USA 90, 133-137.

Boylan, R. J., Mendelson, N. M., Brooks, D. \& Young, F. E. (1972). Regulation of the bacterial cell wall: analysis of a mutant of Bacillus subtilis defective in biosynthesis of teichoic acid. J Bacteriol 110, 281-290.

Clark, D. J. \& Maaløe, O. (1967). DNA replication and the cell division cycle in Escherichia coli. J Mol Biol 23, 99-112.

Claus, D. \& Berkley, R. C. W. (1986). Genus Bacillus. In Bergey's Manual of Systematic Bacteriology, vol. 2, pp. 1105-1136. Edited by P. H. A. Sneath, N. S. Mair, M. E. Sharpe \& J. G. Holt. Baltimore: Williams \& Wilkins.

De Bartolomeo, A., Trotta, F., La Rosa, F., Saltalamacchia, G. \& Mastrandrea, V. (1991). Numerical analysis and DNA base composition of some thermophilic Bacillus species. Int J Syst Bacteriol 41, 502-509.

Degryse, E., Glansdorff, N. \& Piérard, A. (1978). A comparative analysis of extreme thermophilic bacteria belonging to the genus Thermus. Arch Microbiol 117, 189-196.

Del Sal, G., Manfioletti, G. \& Schneider, C. (1989). The CTABDNA precipitation method: a common mini-scale preparation of template DNA from phagemids, phages or plasmids suitable for sequencing. BioTechniques 7, 514-519.

Devereux, J., Haeberli, P. \& Smithies, O. (1984). A comprehensive set of sequence analysis programs for the VAX. Nucleic Acids Res 12, 387-395.

Douthwaite, S., Christensen, A. \& Garrett, R. A. (1983). Higher order structure in the $3^{\prime}$-minor domain of small subunit ribosomal RNAs from a Gram negative bacterium, a Gram positive bacterium and a eukaryote. J Mol Biol 169, 249-279.

Ebbole, D. J. \& Zalkin, H. (1987). Cloning and characterization of a 12-gene cluster from Bacillus subtilis encoding nine enzymes for de novo purine nucleotide synthesis. J Biol Chem 262, 8274-8287.

Eijsink, V. G. H., Vriend, G., Van der Vinne, B., Hazes, B., Van den Burg, B. \& Venema, G. (1992). Effects of changing the interaction between subdomains on the thermostability of Bacillus neutral proteases. Proteins Struct Funct Genet 14, 224-236.

Fahmy, F., Flossdorf, J. \& Claus, D. (1985). The DNA base composition of the type strains of the genus Bacillus. Syst Appl Microbiol 6, 60-65.

Gold, L. (1988). Posttranscriptional regulatory mechanism in Escherichia coli. Annu Rev Biochem 57, 199-233.

Haima, P., Van Sinderen, D., Schotting, H., Bron, S. \& Venema, G. (1990a). Development of a $\beta$-galactosidase $\alpha$-complementation for molecular cloning in Bacillus subtilis. Gene 86, 63-69.

Haima, P., Van Sinderen, D., Bron, S. \& Venema, G. (1990b). An improved $\beta$-galactosidase $\alpha$-complementation system for molecular cloning in Bacillus subtilis, Gene 93, 41-47.

Heinen, U. J. \& Heinen, W. (1972). Characteristics and properties of a caldo-active bacterium producing extracellular enzymes and two related strains. Arch Microbiol 82, 1-23.

Henner, D. J., Band, L., Flaggs, G. \& Chen, E. (1984). Nucleotide sequence of the Bacillus subtilis tryptophan operon. Gene 34, 169-177.

Jensen, K. F., Neuhard, J. \& Schack, L. (1982). RNA polymerase involvement in the regulation of expression of Salmonella typhimurium pyr genes. EMBO J 1, 69-74.
Kagawa, Y., Nojima, H., Nukiwa, N., Ishizuka, M., Nakajima, T., Yasuhara, T., Tanaka, T. \& Oshima, T. (1984). High guanine plus cytosine content in the third letter of codons of an extreme thermophile. DNA sequence of the isopropylmalate dehydrogenase of Thermus thermophilus. J Biol Chem 259, 2956-2960.

Kimsey, H. H. \& Kaiser, D. (1992). The orotidine-5'-phosphate decarboxylase gene of Myxococcus xanthus. Comparison to the OMP decarboxylase family. $J$ Biol Chem 267, 819-824.

Kuroda, M. I., Henner, D. \& Yanofsky, C. (1988). cis-Acting sites in the transcript of the Bacillus subtilis trp operon regulate expression of the operon. J Bacteriol 170, 3080-3088.

Lerner, C. G., Stephenson, B. T. \& Switzer, R. L. (1987). Structure of Bacillus subtilis pyrimidine biosynthetic ( $p y r)$ gene cluster. J Bacteriol 169, 2202-2206.

McLaughlin, J. R., Murray, C. L. \& Rabinowitz, J. C. (1981). Unique features in the ribosome binding site sequence of the Gram-positive Staphylococcus aureus $\beta$-lactamase gene. J Biol Chem 256, 11283-11291.

Neuhard, J. \& Nygaard, P. (1987). Purines and pyrimidines. In Escherichia coli and Salmonella typhimurium: Cellular and Molecular Biology, pp. 445-473. Edited by F. C. Neidhardt, J. L. Ingraham, K. B. Low, B. Magasanik, M. Schaechter \& H. E. Umbarger. Washington, DC: American Society for Microbiology.

Oppenheim, D. S. \& Yanofsky, C. (1980). Translational coupling during expression of the tryptophan operon of Escherichia coli. Genetics 95, 785-795.

Paulus, T. J., McGarry, T. J., Shekelle, P. G., Rosenzweig, S. \& Switzer, R. L. (1982). Coordinate synthesis of the enzymes of pyrimidine biosynthesis in Bacillus subtilis. J Bacteriol 149, 775-778.

Pearson, W. R. \& Lipman, D. J. (1988). Improved tools for biological sequence comparison. Proc Natl Acad Sci US A 85, 2444-2448.

Poulsen, P., Jensen, K. F., Valentin-Hansen, P., Carlsson, P. \& Lundberg, L. G. (1983). Nucleotide sequence of the Escherichia coli pyrE gene and of the DNA in front of the protein-coding region. Eur J Biochem 135, 223-229.

Poulsen, P., Bonekamp, F. \& Jensen, K. F. (1984). Structure of the Escherichia coli pyrE operon and control of pyrE expression by a UTP modulated intercistronic attenuation. EMBO J 3, 1783-1790.

Prescott, L. M. \& Jones, M. E. (1969). Modified methods for the determination of carbamyl aspartate. Anal Biochem 32, 408-419.

Quinn, C. L., Stephenson, B. T. \& Switzer, R. L. (1991). Functional organization and nucleotide sequence of the Bacillus subtilis pyrimidine biosynthetic operon. J Biol Chem 266, 9113-9127.

Roland, K. L., Powell, F. E. \& Turnbough, C. L. (1985). Role of translation and attenution in the control of $p y r B I$ operon expression in Escherichia coli K-12. J Bacteriol 163, 991-999.

Sambrook, J., Fritsch, E. F. \& Maniatis, T. (1989). Molecular Cloning : A Laboratory Manual. Cold Spring Harbor, NY: Cold Spring Harbor Laboratory.

Sanger, F., Nicklen, S. \& Coulson, A. R. (1977). DNA sequencing with chain-terminating inhibitors. Proc Natl Acad Sci USA 74, 5463-5467.

Schlatter, D., Kriech, O., Suter, F. \& Zuber, H. (1987). The primary structure of the psychrophilic lactate dehydrogenase from Bacillus psychrosaccharolyticus. Biol Chem Hoppe-Seyler 368, 1435-1446.

Sharp, R. J., Bown, K. J. \& Atkinson, A. (1980). Phenotype and genomic characterization of some thermophilic species of Bacillus. $J$ Gen Microbiol 117, 201-210.

Spizizen, J. (1958). Transformation of biochemically deficient strains of Bacillus subtilis by deoxyribonucleate. Proc Natl Acad Sci US A 44, 1072-1078. 
Sørensen, K. I. \& Neuhard, J. (1991). Dual transcriptional initiation sites from the pyrC promoter control expression of the gene in Salmonella typhimurium. Mol \& Gen Genet 225, 249-256.

Sørensen, K. I., Baker, K. E., Kelln, R. A. \& Neuhard, J. (1993). Nucleotide pool sensitive selection of the transcriptional start site. $J$ Bacteriol 175, 4137-4144.

Tuerk, C., Gauss, P., Thermes, C., Groebe, D. R., Gayle, M., Guild, N., Stormo, G., D'Aubenton-Carafa, Y., Uhlenbeck, O. C., Tinoco, I., Brody, E. N. \& Gold, L. (1988). CUUCGG hairpins: extraordinarily stable RNA secondary structures associated with various biochemical processes. Proc Natl Acad Sci US A 85, 1364-1368.

Wilson, H. R., Archer, C. D., Liu, J. \& Turnbough, C. L. (1992). Translational control of pyrC expression mediated by nucleotidesensitive selection of transcriptional start sites in Eschericbia coli. $J$ Bacteriol 174, 514-524.

Van den Burg, B., Enequist, H. G., Van der Haar, M. E., Eijsink, V. G. H., Stulp, B. K. \& Venema, G. (1991). A highly thermostable neutral protease from Bacillus caldolyticus. Cloning and expression of the gene in Bacillus subtilis and characterization of the gene product. $J$ Bacteriol 173, 4107-4115.

Zalkin, H. \& Ebbole, D. J. (1988). Organization and regulation of genes encoding biosynthetic enzymes in Bacillus subtilis. J Biol Chem 263, 1595-1598.

Zuber, H. (1988). Temperature adaptation of lactate dehydrogenase. Structural, functional and genetic aspects. Biophys Chem 29, 171-179.

Zuker, M. \& Stiegler, P. (1981). Optimal computer folding of large RNA sequences using thermodynamics and auxiliary information. Nucleic Acids Res 9, 133-148.

Zulli, F., Weber, H. \& Zuber, H. (1987). Nucleotide sequences of lactate dehydrogenase genes from the thermophilic bacteria Bacillus stearothermophilus, B. caldolyticus, and B. caldotenax. Biol Chem HoppeSeyler 368, 1167-1177.

Received 20 July 1993; revised 27 September 1993; accepted 1 October 1993. 